\title{
Kościół św. Mikołaja w Wolinie. Losy budowli w latach 1945-1988
}

Artykut jest pierwsza czéścia materiatu poświęconego powojennej bistorii kościola sw. Mikotaja w Wolinie. Przedstawiono w nim losy zrujnowanej swiatyni od momentu prajejecia pręez państwo do chwili, kiedy pod koniec lat 80. Kościót katolicki po raz kolejny podjat driatania na recer jej odzyskania i odbudowy'.

Tościół św. Mikołaja w Wolinie zbudowano między schyłkiem XIII
wieku a druga ćwiartką wieku XIV ${ }^{2}$. Trudno jednak określić dokładny czas powstania świątyni ze względu na skappy materiał źródłowy oraz różną jego interpretację $e^{3}$. Pisano o XII- ${ }^{4}$ jak i XV-wiecznym pochodzeniu kościoła ${ }^{5}$. W ostatnim czasie budowę świątyni datuje się na 1288 r. $^{6}$

1 Drugą część poświęcono działaniom Kocioła na rzecz odbudowy i procesowi dobudowy świątyni w latach 1988-1999(2003).

2 Zob. K. Kalita, Historia i budowa kościoła św. Mikołaja w Wolinie, „Materiały Zachodniopomorskie" 1972, t. XIX, s. 471.

3 Problematyką zajmowali się między innymi: H. Lemcke, Die Bau und Kunstdenkmäler des Regierungsbezirks Stettin, z. IV, Stettin 1900; E. Winecke, Untersuchungen zur Religion der Westslawen, Leipzig 1940; A. Holz, Die Wolliner Missions und Stadt - Kirchen und das dortige norddeutsche Heiligtum, „Monatsblätter” r. 54, Stettin 1940.

4 E. Winecke, op.cit., s. 234-236.

5 H. Dollen, Streifïrige durch Pommern, t. 2, z. 6, 1885, s. 64; F. Kugler, Pommersche Kunstgeschichte, „Baltische Studien” N.F., 1840, t. 8, s. 133.

6 R. Kostynowicz, Kościoty Archidiecezji Szczecinsko-Kamieńskiej, t. II, Szczecin 2000, s. 450; Archidiecerja Szrzecińsko-Kamieńska w roku tryydziestopieciolecia 1972-2007, Szczecin 2007, s. 542. W jednym z opracowań z 1989 r. napisano, że „o ile przyjmie się, że był budowlą muro- 
Dokładniejszego określenia czasu powstania budowli można dokonać po ewentualnym przeprowadzeniu badań archeologicznych?

Ceglana świątynia, pierwotnie bezchórowa, została zbudowana na planie prostokąta. Trójnawową halę pozbawiona prezbiterium wzbogacono masywną wieżą na rzucie kwadratu, dobudowaną od strony zachodniej.

W XV wieku przebudowano kościół. Powodem było najprawdopodobniej osłabienie konstrukcji świątyni, powstałe na skutek obsuwania się gruntu spod budowli'. W trakcie prac zastosowano bogaty detal architektoniczny, który zachował się tylko na półfilarach ${ }^{10}$. W 1628 r. w trakcie wojny trzydziestoletniej Wolin prawie w całości spłonął. Pożar nie oszczędził także kościołów miasta. Odbudowę świątyni św. Mikołaja ukończono dopiero u schyłku XVII wieku ${ }^{11}$. W wieku XIX stan budowli był tak zły, że rozpoczęto prace zabezpieczające, a następnie podjęto decyzję o jego przebudowie ${ }^{12}$. „Wówczas to wyburzono zupełnie ściany naw bocznych i postawiono je na nowo w stylu neogotyckim. Przebudowano także częściowo ścianę wschodnią, a partię szczytu zrekonstruowano w 1898 r. W tym okresie przebudowano również trzecią kondygnację wieży"13. W pierwszej połowie XX wieku przy świątyni nie prowadzono żadnych poważniejszych prac.

Druga wojna światowa pozostawiła swoje piętno na tzw. Ziemiach Odzyskanych. Traktowanie ich w sposób szczególny przez „armię wyzwoleńczą" doprowadziło do ogromnych zniszczeń. Biorąc pod uwage raporty pełnomocników rządu z lat 1945-1946, zniszczenia wojenne w miastach

wana, to przebudowano ją na przełomie XIII i XIV w.". Zob. Archiwum Wojewódzkiego Urzędu Ochrony Zabytków w Szczecinie (AWUOZS), Z. Becker, I. Kukla, St. Kwilecki, B. Kozińska, J. Nekanda-Trepka, Kościót p.w. św. Mikotaja w Wolinie. Projekt koncepcyjny odbudowy - czessí ogólna, Szczecin 1989, s. 5.

Jak sugeruje Kalita, op.cit. s. 447.

8 R. Kostynowicz, op.cit., s. 450; K. Kalita, op.cit., s. 448.

9 K. Kalita, op.cit., s. 472.

10 Ibidem, s. 472. Przebudowano wówczas filary i zasklepiono ponownie wnętrze świątyni.

11 Zob. H. Lemcke, op.cit., s. 412.

12 K. Kalita, op.cit. s. 458, pisała o rozpoczęciu odbudowy: „Generalną odbudowę zaczęto w 1860 r.".

13 Ibidem, s. 462. 
Pomorza Szczecińskiego szacowano średnio na 50,4\%, przy czym w wielu ośrodkach były one dużo większe ${ }^{14}$. W Wolinie zniszczenia substancji budowlanej sięgały $80 \%{ }^{15}$. Dodać należy, że najbardziej zdewastowane obiekty zabytkowe na Ziemiach Zachodnich i Północnych znajdowały się w województwie szczecińskim - szacunkowo w 70\% ${ }^{16}$. Kościół św. Mikołaja był jedna z najbardziej zrujnowanych budowli ${ }^{17}$. W 1946 r. Pełnomocnik Rządu RP na Obwód Uznam-Wołyń [Wolin - autor] komunikował: „w odpowiedzi na pismo [...] zniszczone zabytki architektoniczne, znajduja się jedynie w naszym obwodzie w mieście Wołyniu. Zabytki te sa w stanie zupełnej ruiny i jakkolwiek ich odbudowa jest w obecnych warunkach prawdopodobnie w ogóle nieaktualna"18. Ze względu na sytuację panująca bezpośrednio po zakończeniu drugiej wojny światowej - tworzenie od podstaw katolickiej administracji kościelnej oraz brak odpowiedniej liczby duchownych ${ }^{19}$ Kościół w pierwszym rzędzie przejmował świątynie niezniszczone, bądź zdewastowane $\mathrm{w}$ niewielkim stopniu ${ }^{20}$. Władze państwowe zasadniczo nie czyniły trudności w przejmowaniu takich świątyńn ${ }^{21}$.

14 H. Orlińska, B. Skula, Budownictwo i ustugi gospodarcze, [w:] Pomorze Szczecińskie 1945-1965, red. Z.E. Dobrzycki, H. Lesiński, Z. Laski, Szczecin 1967, s. 462-463.

15 Ibidem, s. 462.

16 Polska Zachodnia i Pótnocna, red. J. Kruczyńska, Poznań 1961, s. 493.

17 K. Kalita, op.cit., s. 462 pisze o zniszczeniach około 80\%. Według oceny Bończa-Bystrzyckiego w tak wielkim stopniu było zrujnowanych około 200 kościołów, w przeważającej mierze zabytkowych. Por. L. Bończa-Bystrzycki, Zniszczenia budynków kultu religijnego podczas II wojny światowej na terenie diecerji szczecińsko-kamieńskiej, „Prezbiterium” 6-8(1974), s. $72-73$.

18 AWUOZS, sygn. II/87, Zabytki nieruchome pow. Wolin, karta 277: Petnomocnik Rzqdu RP na Obwód Uz̧nam-Wotyń w Świnoujściu. Referat Kultury i Sztuki, Świnoujście, dnia, 30 maja 1946 r., Do Urzedu Petnomocnika RP na Okreg Pomorze Zachodnie Wydziat Kultury i Sztuki w) Szrzecinie.

19 W 1946 r. na Pomorzu Zachodnim pracowało około 150 księży. W 1948 r. liczba duchownych zmniejszyła się. Dopiero w 1956 r. pracowało w regionie ok. 350 księży. Zob. K. Kowalczyk, $W$ walce o rzad dus\%. Polityka wład₹, państwonych wobec Kościoła katolickiego na Pomorzu Zachodnim w latach 1945-1956, Szczecin 2003, s. 71. Administracja Apostolska Kamieńska, Lubuska i Prałatury Pilskiej była największą administracją nie tylko w Polsce, ale i w całej Europie.

20 Zob. R. Kostynowicz, Diecezjalny konserwator, „Szczecińskie Studia Kościelne” 7-10(1997-2000), s. 296.

21 Zob. B. Frankiewicz, Poczatki polskiej administracii kościelnej na Pomoræu Zachodnim w latach 1945-1947, „Przegląd Zachodniopomorski” 1(1986), s. 72-73; H. Kołodziejek, Przejmowa- 
Sytuacja uległa radykalnej zmianie u schyłku lat 40. XX wieku. Wówczas zahamowano proces przekazywania budowli sakralnych prawowitym właścicielom ${ }^{22}$. Zrujnowany kościół św. Mikołaja pozostał własnością Skarbu Państwa - Prezydium Miejskiej Rady Narodowej w Wolinie ${ }^{23}$.

W wyniku wojny oraz powojennych rozbiórek i dewastacji zostało zrujnowanych wiele zabytkowych obiektów, w tym kościołów. Budowle sakralne na Pomorzu Zachodnim z całą pewnością wpisują się w pojęcie zabytku i dobra kultury. Stan zachowania obiektów sakralnych był wypadkową wielu czynników, między innymi trudnych relacji Kościoła katolickiego z państwem, zwłaszcza na terenach Ziem Zachodnich i Północnych oraz „właściwego" traktowania zabytkowej architektury sakralnej przez władze wyznaniowe i niejednokrotnie służby konserwatorskie. Przykładem, który pokazuje wpływ wymienionych determinantów na stan zachowania budowli, jest kościół św. Mikołaja w Wolinie. Jak wspomniano, zniszczenia świątyni określano na poziomie 80\%. Lektura dokumentacji z Archiwum Wojewódzkiego Urzędu Ochrony Zabytków w Szczecinie daje jednak nieco inny pogląd. Z karty obiektu zabytkowego wynika, że w 1945 zanotowano zniszczenie dachu, łuków naw oraz rozbicie wieży. Zniszczenia oszacowano na $50 \%{ }^{24}$. Do początku lat pięćdziesiątych żadnych prac zabezpieczających nie wykonano. Doprowadziło to do radykalnego pogorszenia stanu zachowania już i tak w znacznym stopniu zniszczonego obiektu. Efektem było wnioskowanie o rozbiórkę wschodniego szczytu kościoła. Z taką inicjatywą wystapiło Prezydium Miejskiej Rady Narodowej w Wolinie ${ }^{25}$. Z korespondencji wynika, że ostatecznie zakres prac rozbiórkowych poszerzono

nie i pręekasywanie nieruchomości do usiytku kościelnego w województwie szczecinskim w latach 1945-1971, „Przegląd Zachodniopomorski” 1-2(1988), s. 257.

22 Zob. J. Gałecki, Budownictwo sakeralne w cəterdzৃiestoleciu, „Prezbiterium” 1-5(1985), s. 96; G. Wejman, Organizacja Kościoła katolickiego na Pomoræu Zachodnim i Ziemi Lubuskiej w latach 1945-1972, Szczecin 2007, s. 203.

23 AWUOZS, Karta Obiektu Zabytkowego (KOZ), Kościót p.w. sw. Mikołaja. Wolin, Szcze$\operatorname{cin} 1959$ (?).

${ }^{24}$ Ibidem. Z pewnością w zapisie pominięto uszkodzenia szczytu ściany wschodniej.

25 Zob. AWUOZS, sygn. II/87, karta 295: Presydium Miejskiej Rady Narodowej w Wolinie,

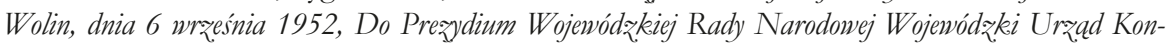
serwatorski w Szrzecinie. Ob. magst. Kraymuska Konserwator Wojewódæki. 
o inne ściany ${ }^{26}$. Powstał spór, w czyjej kompetencji leży zrealizowanie prac rozbiórkowych. Wydział Kultury Prezydium Wojewódzkiej Rady Narodowej w Szczecinie uzasadniał, zresztą słusznie, że nie jest zobowiązany do przeprowadzenia prac z tego względu, że nie jest właścicielem obiektu ${ }^{27}$. Ostatecznie pismo w tej sprawie skierowano do Prezydium Miejskiej Rady Narodowej w Wolinie. „Wydział Budownictwa działając na podstawie art. 377 prawa budowlanego poleca Prezydium MRN, jako prawnemu właścicielowi ruin ww. kościoła rozebrać zagrożone ściany do wysokości miejsca zagrożenia"28. Mimo że świątynia nie została przekazana Kościołowi, kuria ordynariatu w Gorzowie Wielkopolskim wystapiła w latach 1952-1953 z odpowiednimi wnioskami do Ministerstwa Kultury i Sztuki oraz Konserwatora Wojewódzkiego w Szczecinie o „subwencje na odbudowę, względnie na zabezpieczenie zabytkowego kościoła"29. Można przypuszczać, że po odwilży w 1956 r. ordynariusz gorzowski skierował postulat o przekazanie ruin świątyni w Wolinie, podobnie jak kościołów w innych miejscowościach Pomorza Zachodniego. Władze wyznaniowe przekazały wówczas w całej Administracji Apostolskiej 73 budowle sakralne, jednak nie wyraziły zgody na oddanie obiektu w Wolinie ${ }^{30}$. Kościół św. Mikołaja wpisano do rejestru zabytków w 1959 r. ${ }^{31}$ Biorąc pod uwagę historyczne aspekty, znaczenie dla regionu oraz negatywne w swym znaczeniu liczne przebudowy na przestrzeni wieków, budowlę zakwalifikowano do II grupy ${ }^{32}$. Nie zmieniło to w zasadniczy sposób losów zrujnowanego zabytku. Już wcześniej,

26 Ibidem, karta 227: Presydium Wojewódzkiej Rady Narodowej w Szczecinie Wydziat Budownictwa, Szczecin, dnia 9 grudnia 1952 r., Prezydium Miejskiej rady Narodowej Wolin.

27 Ibidem, karta 224: Wydział Kultury, K.N.VI-57/52, Szczecin, dnia 24 listopada 1952 r., Do Wydriatu Budownictwa w gmachu; karta 296: KN 57/52, Szczecin, dnia 16 września 1952 r., Do Presydium Miejskiej Rady Narodowej w Wolinie.

28 Ibidem, karta 227.

29 Ibidem, karta 228: Kuria Ordynariatu w Gorzowie Wlkp., Gorzón Wlkp., dnia 19 sierpnia 1953 r., Do Prezydium Wojewódzkiej Rady Narodowej Wydział Kultury i Sztuki Konserwator Wojew. w Szrecinie.

30 Zob. G. Wejman, op.cit., s. 207-208; Nowe kościoty oddane katolikom, „Gorzowskie Wiadomości Kościelne” 7-8(1957), s. 472; Dalsz̧e kościoły oddane katolikom, „Gorzowskie Wiadomości Kościelne" 8(1958), s. 450.

31 AWUOZS, KOZ, Kościót p.w. św. Mikołaja. Wolin. Szczecin 1959.

32 Ibidem. Duże znaczenie dla takiej kwalifikacji, miała ogólna sytuacja w zakresie ochrony zabytków, po wojnie, a w szczególności na Pomorzu Zachodnim. 
w 1957 r., Konserwator Wojewódzki w Szczecinie odpowiadając kurii biskupiej w Gorzowie Wielkopolskim, zwrócił uwagę, że „dotychczas nie ustalono wytycznych co do sposobu konserwacji ruin obwodowych kościołów w Wolinie. Trudność zajęcia ostatecznego stanowiska w tej sprawie wynika z dziwiętnastowiecznej przebudowy całych partii ścian zewnętrznych, przez co straciły one na wartości szczególnie w wypadku, jeżeli miano by je traktować, jako stałe ruiny. W skali zniszczeń wojennych, którym uległy zabytkowe kościoły konserwacja ruin w Wolinie, jest zaplanowana w późniejszym terminie po przeprowadzeniu koniecznych prac konserwatorskich przy obiektach cenniejszych jak np. kościół Mariacki w Chojnie, kościół w Pyrzycach itd." 33 . Pozostawienie bez opieki światyni w Wolinie oraz brak konkretnych działań w zakresie przyszłego kształtu obiektu doprowadziło do szkodliwych incydentów. Władze kościelne pisały: „Pismem z 30.I.57 znak: F I 1 i - 1/57 - zwróciliśmy się do Wojewódzkiego Konserwatora Zabytków w sprawie zabytkowej nieczynnej katedry w Wolinie z prośba o interwencję i pomoc celem zabezpieczenia zabytku przed zniszczeniem i kradzieżami. Ostatnio skradziony został dzwon z wieży katedry. Konserwator Zabytków nie udzielił żadnej odpowiedzi mimo upływu 3 miesięcy i nie podjął żadnej czynności celem zabezpieczenia niszczejącego i rozkradzionego [rozkradanego - autor] zabytku" ${ }^{34}$. Po sześciu miesiącach od zgłoszenia kradzieży Wojewódzki Konserwator Zabytków w Szczecinie odpowiedział: „wykradziony dzwon został odnaleziony i obecnie zabezpieczony na Zamku szczecińskim". We wspomnianej odpowiedzi był zawarty jeszcze komentarz: „nadmieniamy, że dzwon ten nie przedstawia wartości zabytkowej”’35. Trudno z dzisiejszej perspektywy odnieść się do tego stwierdzenia ${ }^{36}$.

33 AWUOZS, sygn. II/87, karta 321: Preaydium Wojewódzkiej Rady Narodowej w Szczecinie. Wydziat Kultury, Szrzecin, dnia 9 lipca 1957 r., Kuria Biskupia w Gorzowie Wielkopolskim, ul. Dryymaty.

34 Ibidem, karta 323: Kuria Biskupia w Gorzonie Wlkp., Gorzón Wlkp., dnia 8 maja 1957 r., Presydium Wojewódžkiej Rady Narodowej na ręce p. Prz̨ewodniczacego Szczecin.

35 Ibidem, karta 321.

36 Według inwentarza sporządzonego pod koniec XIX w., w kościele były 3 dzwony: dzwon z 1494 r. wykonany w pracowni Rogghemana w Rostocku, dzwon zegarowy, dekorowany herbem Wolina (XV w.) oraz dzwon z napisem w gotyckiej minuskule (ok. 1500 r.). Zob. AWUOZS, Karta Ewidencji Zabytków Architektury i Budownictwa (KEZAiB), Raymmsko-katolicki 
W 1958 r. napisano: „w nawiązaniu do przeprowadzonej rozmowy Wojewódzki Konserwator Zabytków w Szczecinie zamierza przeprowadzić konserwację ruin kościoła św. Wojciecha z zachowaniem ich, jako trwałej ruiny. Stan zniszczenia obiektu oraz duża jego wartość historyczna uzasadnia powyższe stanowisko. Zdaniem naszym roboty przy tym obiekcie powinny być zakończone do roku 1962"37. Wcześniej, w 1956 r., Wojewódzki Konserwator Zabytków w Szczecinie w opinii do studium historyczno-urbanistycznego do planu zagospodarowania przestrzennego miasta Wolina, wykluczał kategorycznie odbudowę kościoła ze względu na wcześniejsze przeróbki naruszające substancję zabytku. Według Konserwatora do ewentualnej odbudowy nadawał się jedynie kościół św. Jerzego, a nie jak proponowano kościół św. Mikołaja ${ }^{38}$. Jak wiemy, nie doszło do odbudowy świątyni pw. św. Jerzego. Budowlę systematycznie rozbierano, aż w 1963 r. ówczesny kierownik Wydziału ds. Wyznań Prezydium Wojewódzkiej Rady Narodowej w Szczecinie wyraził oficjalnie zgodę na rozbiórkę zniszczonego kościoła. Wniosek w tej sprawie wystosowały władze powiatowe w Świnoujściu ${ }^{39}$. Pretekstem do rozbiórek nieużytkowanych, częściowo zrujnowanych budowli sakralnych była likwidacja istniejących śladów zniszczeń wojennych w miastach i na osiedlach oraz ruin i obszarów zagruzowanych, a także wykorzystanie w związku z tym materiałów budowalnych i zużytkowanie gruzu do produkcji tych materiałów. Działania w tym zakresie regulowała słynna „Uchwała 666”40. W praktyce zarza-

kościót parafialny p.w. św. Mikołaja. Wolin, Szczecin 1999. Trudno stwierdzić, czy dzwony przetrwały do lat powojennych, ale też nie można zaprzeczyć, że to był któryś w nich.

37 AWUOZS, sygn. II/87, karta 222: KL.III-1/251/61, 22 czerwca 61, ul. Rycerska, Presydium Miejskiej Rady Narodowej Wolin. Wcześniej, w 1956 r. Wojewódzki Konserwator Zabytków w Szczecinie wydał opinię do studium historyczno-urbanistycznego do planu zagospodarowania przestrzennego miasta Wolina, w której wykluczył kategorycznie odbudowę kościoła ze względu na wcześniejsze przeróbki, naruszające substancję zabytku.

38 WUOZS, sygn. II/87, karta 210-211: OPINLA Wojewódqukiego Konserwatora Zabytkón w Szczecinie dotyczaca studium Historyczno-urbanistycznego do planu zagospodarowania przestrzennego miasta Wolina. Zob. Idem, karta 328.

39 Ibidem, karta 265: Prezydium Wojewódækiej Rady Narodowej Wydziat do Spraw Wyznań, Szczecin, dnia 25 lipca 1968, Poufne Obywatel Przewodniczacy Presydium Powiatowej Rady Narodowej w Świnoujściu.

40 Uchwała Nr 666 Prezydium Rządu z 20 VIII 1955 r. w sprawie planowej akcji usunięcia pozostałości zniszczeń wojennych w miastach i osiedlach, M.P., Nr 92, poz. 1189. 
dzone „porządkowanie” prowadziło do patologii. W panującej po wojnie nowej politycznej rzeczywistości, pod pretekstem likwidacji zniszczeń wojennych, wykorzystując regulacje prawne rozebrano wiele zabytkowych kościołów ${ }^{41}$.

Sobór Watykański II, w trakcie którego prowadzono nieoficjalne rozmowy o utworzeniu polskich biskupstw na trenach Ziem Zachodnich i Północnych oraz obchody milenijne i pogarszające się relacje Kościoła katolickiego z państwem zmieniły położenie świątyni w Wolinie. Władze państwowe nie myślały jednak o przekazaniu wiernym ruin kościoła w celu ich odbudowy dla potrzeb kultu, lecz postanowily przeznaczyć obiekt na cele świeckie, zachowując w ten sposób stan posiadania. W połowie lat 60. do władz konserwatorskich w Szczecinie skierowano prośbę o wyrażenie zgody na „odbudowę i adaptowanie katedry zabytkowej w Wolinie przy ul. Wojska Polskiego z przeznaczeniem na salę widowiskowo-rozrywkową, której to $\mathrm{m}$. Wolin w ogóle nie posiada" ${ }^{\prime 2}$. Planowano odbudowanie wieży z przeznaczeniem na punkt widokowy, zlokalizowanie w wieży kiosku z pamiątkami i biura PTTK oraz muzeum ziemi wolińskiej. Odbudowa kościoła miała być prowadzona $z$,zachowaniem jego stylu wewnętrznego i zewnętrznego, pozostawiając funkcje zabytku” z tym, że wewnątrz planowano wykonanie sali widowiskowej ze sceną ${ }^{43}$. Planując zachowanie budowli, co najwyżej w charakterze trwałej ruiny, władze konserwatorskie poparły inicjatywę, obiecując wykonanie niezbędnej dokumentacji obiektu wraz

${ }^{41}$ Np. Rozbiórka zabytkowych kościołów (XIII wiek) w Ustowie i Warzynicach. Zob. AWUOZS, sygn. II/84, karta 162: Zabytki nieruchome pow. Szczecin: Presydium Wojewódz̨kiej Rady Narodowej w Szczecinie Wydziat Kultury, Szczecin, dnia 22 stycznia 1958 r., Ministerstwo Kultury i Sztuki Centralny Zarzqd Muzeón i Ochrony Zabytkón Warszawa. Zobacz dalsze karty: 161, 159, 158, 155, 147, 148, 142, 143; Rozbiórka zabytkowego kościoła w Dołujach. Zob. idem, karta 143; Rozbiórka zabytkowego kościoła w Siodle Górnym. Zob. idem, karta 121, 122, 123, 124; Sprawa kościoła w Brzózkach. Zob. idem, karta 8, 9; Kościół w Tarnówku. Zob. AWUOZS, sygn. II/160, Zabytki nieruchome - sprawy typowania przez Prezydia Miejskich i Powiatowych Rad Narodowych obiektów zabytkowych do rozbiórki, karta 13, 14; Sprawa kościołów w Wrzosowie i Sibinie. Zob. idem, karta 18, 34, 48, 60; Przypadek kościoła w Strzmielach. Zob. idem, karta 64, 65.

42 AWUOZS, sygn. II/87, karta 269: Zakład Gospodarki Komunalnej i Mieszkaniowej w Wolinie, Wolin, dnia 9 kwietnia 1965 r., Wojewódそki Konserwator Zabytkón w Szczecinie ul. Rycerska 3.

43 Ibidem, karta 269. 
z wytycznymi do odbudowy ${ }^{44}$. Prac nie rozpoczęto. Natomiast w 1968 r. zlecono wykonanie projektu na zabezpieczenie kościoła jako trwałej ruiny. Projekt został opracowany przez inż. arch. Lopacińskiego. Autor przedstawił w nim dwa alternatywne rozwiązania: „I - urządzenie trwałej ruiny przy zachowaniu murów z pierwszej fazy, do której zalicza wieżę, ścianę wschodnią i filary $\mathrm{z}$ arkadami), a rozebranie do fundamentów neogotyckich ścian naw bocznych. II - ze względu na dość dobry stan murów neogotyckich autor proponuje przykrycie kościoła dachem płaskim i wykorzystanie go do celów użytkowych - przy czym nie byłaby to odbudowa, a jedynie zabezpieczające zamknięcie obiektu jako ruiny" ${ }^{35}$. Przy realizacji projektu wybrano wariant I - skierowanie prac zabezpieczających tylko na wybrane elementy budowli wraz z przystosowaniem wieży do funkcji punktu widokowego ${ }^{46}$. Do końca 1971 r. kościół częściowo zabezpieczono ${ }^{47}$, jednak rok później rozebrano partię ściany południowo-zachodniej nawy bocznej, będącej w zupełnie dobrym stanie ${ }^{48}$. Mając w pamięci losy kościoła św. Jerzego, władze kościelne zaprotestowały przeciw takiemu postępowaniu, tym bardziej, że ruiny świątyni św. Mikołaja zostały umieszczone na liście obiektów wnioskowanych o przekazanie Kościołowi ${ }^{49}$.

44 Ibidem, karta 268: Nr KL.21/95/65, Szczecin, dnia 13 maja 1965 r., Zakład Gospodarki Komunalnej i Mieszkaniowej Wolin.

${ }^{45}$ K. Kalita, Kościót św. Mikołaja w Wolinie. Dokumentacja bistoryczno-architektoniczna, PKZ Szczecin 1973, s. 31-32. Zob. AWUOZS, sygn. II/247, karta 13: Notatka stu̇̌bowa spisana $w$ dniu 29.04.1968 r. w sprawie ustaleń przedumownych opracowania projektowego dla ruin kościola $w$ Wolinie.

46 K. Kalita, Kościót św. Mikotaja..., s. 32.

47 Prace były prowadzone nieregularnie i miały opóźnienia. W sprawie interweniowały władze powiatowe w Świnoujściu. „Środkami na Kościoła św. Mikołaja i skansen nie dysponujemy (nie ma ich w budżecie powiatowym). Nie widzimy postępu przy remoncie Kościoła w Wolinie, od wielu miesięcy stoją tylko rusztowania”. AWUOZS, sygn. II/247, karta 91: Presydium Powiatowej Rady Narodowej w Świnoujściu, Świnoujscie, dnia 24.V.1974 r., Wydziat Kultury Presydium Wojewódzkiej Rady Narodowej Szczecin.

${ }^{48}$ K. Kalita, Kościót sww. Mikotaja..., s. 32. Zob. też: M. Bujwid, Kościót św. Mikotaja, Kosztorys - wycena wstęna, PKZ Szczecin 1972; T. Zajączkowski, Kościót sw. Mikołaja, Projekt ramy zabezpieczajacej, PKZ Szczecin 1973.

${ }_{49}$ Listę obiektów przygotowywano do Uchwały Rady Ministrów. „W nawiązaniu do pisma z dnia 7.XI.1972 r., l.dz. 172 uprzejmie komunikujemy, że w dniu 7 XI 1972 r., Ks. Mgr Roman Kostynowicz, Wikariusz Biskupi, złożył protest w związku z przeprowadzoną rozbiórką w Wydziale ds. Wyznań PWRN i u Konserwatora Wojewódzkiego. 
Pojawiły się „techniczne trudności” opracowania projektu konstrukcji dla zatwierdzonej koncepcji architektonicznej. Ustalono, że projekt będzie opracowany dopiero „po uprzednim rozpatrzeniu koncepcji trwałego zabezpieczenia przez Radę Konserwatorska pod względem zachowania poszczególnych części nawarstwień obiektu"50. Można zauważyć brak jednolitego poglądu służb konserwatorskich i innych instytucji w sprawie opracowania ostatecznej koncepcji dotyczącej dalszych losów zrujnowanego Kościoła. Wreszcie w 1973 r. ustalono wspólne stanowisko ${ }^{51}$. „Najcenniejszymi elementami w obecnej bryle ruiny kościoła św. Mikołaja w Wolinie są: środkowa część ściany wschodniej, zachowane filary wraz z arkadami oraz wieża. Neogotyckie ściany podłużne i szczytowe naw bocznych pełnia funkcję elementu usztywniającego obiekt do czasu zabezpieczenia". Stwierdzono konieczność wzmocnienia filarów (zamurowanie wyrw), reperację korony arkad i położenie wieńca żelbetowego, wzmocnionego wpustami w miąższ muru w pionach filarów, przemurowanie łuku okiennego przy narożu północno-wschodnim, zabezpieczenie korony ściany wschodniej i związanie jej z arkadami oraz wolnostojącymi filarami za pomoca poziomej ramy, oczyszczenie lica zewnętrznego wieży i pozostawienie go w stanie surowym oraz zabezpieczenie wieży przez założenie dwóch stropów żelbetowych i płyty poniżej korony murów, traktując poziom tego przykry-

Powołał się przy tym, że obiekt ten jest wpisany pod nr 136 z 2 artykułu i II kwestionariusza" - Archiwum Konserwatora Diecezji Szczecińsko-Kamieńskiej w Szczecinie (AKDSK), Teczka woj. Szczecin, Dekanat Świnoujście: Szrzecinsko-Kamieńska, Szczecin, 15 listopada 1972, Znak: LW 14 - 5/72, Wielebny Ks. Proboszrz. Zygmunt Frelika, Wolin. „Cegłę z rozbiórki ładują na przyczepy ciagnikowe i zaraz wywożą na jakąś inną budowę. Kiedy zapytałem pracowników, gdzie jest kierownik, powiedzieli, że o cegłę nie warto pytać, bo i tak nie dostanę" - Idem: Urzad Parafialny Wolin Pom, Wolin Pom., dnia 7 listopada 1972 r., Do Kurii biskupiej w Srezecinie.

50 AWUOZS, sygn. II/247, karta 52: Protokót spisany dnia 26.01.1972 r. w sprawie dokumentacji dla kościoła św. Mikołaja w Wolinie pray udziale: inæ. St. Kwilecki, dr Z. Radacki, mgr r. Kasinowska, in $\dot{\%}$. Bujwid, in $\dot{\%}$ Z. Ruczkonski. Rozpatrywano wariant trwałego, jak i czasowego zabezpieczenia ruin.

51 Spotkanie przedstawicieli wojewódzkich służb konserwatorskich, PP Pracowni Konserwacji Zabytków w Szczecinie, projektanta konstrukcji, autora dokumentacji historycznej oraz kierownika budowy. Zob. AWUOZS, sygn. II/247, karta 77: Protokót spisany w dniu 30.03.1973 r. na budowie ruiny Kościoła św. Mikołaja w Wolinie. 
cia jako platformę widokowa ${ }^{52}$. W 1974 r. przygotowano projekt techniczny „Taras widokowy na wieży”, w którym potwierdzono kierunek prac: „Niniejsze opracowanie skoncentrowano na murach gotyckich, które w myśl zalecenia PWRN WK [Prezydium Wojewódzkiej Rady Narodowej. Wydział Kultury - autor] mają być zabezpieczone w trwała ruinę. Ściany zewnętrzne naw z krużgankami podłużne i szczytowe wybudowane w wieku XIX w stylu neogotyckim przeznaczone są do rozbiórki" ${ }^{53}$. Prace zabezpieczające przy murach oraz przy adaptacji wieży trwały wiele lat ${ }^{54}$. W $1980 \mathrm{r}$. służby konserwatorskie dokonały wpisu w Karcie Obiektu Zabytkowego: „13.XI.1980 - trwała ruina” ${ }^{\prime 2}$.

Pod koniec lat 60., kiedy wprowadzano w życie projekt zabezpieczenia świątyni jako trwałej ruiny, władze kościelne rozpoczęły po raz kolejny rozmowy na temat przekazania Kościołowi nieużytkowanych obiektów sakralnych. Przełomem w tej kwestii było podpisanie układu między Polską a RFN, który umożliwił podjęcie przez polski episkopat i Stolicę Apostolską odpowiednich działań na rzecz „normalizacji sytuacji Kościoła na Ziemiach Zachodnich i Północnych Polski" ${ }^{56}$, a tym samym losów nieużytkowanych budowli sakralnych ${ }^{57}$. Ustawa uchwalona przez Sejm dała podstawy do starań o przekazanie zrujnowanego kościoła św. Mikołaja ${ }^{58}$.

52 Ibidem. Zob. też AWUOZS, sygn. 1202, Zabytki nieruchome. Wolin - Kościół św. Mikołaja: Wolin, dnia 7 listopada 1974, Mu₹eum Regionalne w Wolinie do Wojewódzkiego Konserwatora Zabytkón Szczecin.

53 AWUOZS, T. Zajączkowski, Taras widokowy na wieşy. Projekt techniczny, PKZ Szczecin 1974.

${ }^{54}$ Zob. AWUOZS, sygn. II/247, Zabytki nieruchome. Wolin, karta 85, 77, 78, 91, 112.

55 Zob. AWUOZS, KOZ, Kościót św. p.w. Mikołaja. Wolin, Szczecin 1959.

56 Zob. P. Fenrych, Diecezja Szczecińsko-Kamieńska w XV-leciu. Kalendarium, „Prezbiterium” 1-3(1987), s. 88.

${ }^{57}$ W 1965 r. zwracano uwagę, że w Administracji Apostolskiej (między innymi teren dzisiejszej Archidiecezji Szczecińsko-Kamieńskiej) „Władze administracyjne [...] wręcz uniemożliwiały odbudowę cennych zabytków”. Archiwum Diecezji Zielonogórsko-Gorzowskiej (ADZG), sygn. 1093, Korespondencja z władzami świeckimi 1963-1972: W imienin Księ̇y dekanalnych Driekani (3.06.1965 r.), Do Rzqadu Polskiej Rzecsypospolitej Ludowej na rece Premiera Józefa Cyrankiewicza Warszawa.

58 Ustawa o przejściu na osoby prawne Kościoła rzymskokatolickiego oraz innych kościołów i związków wyznaniowych własności niektórych nieruchomości położonych na Ziemiach Zachodnich i Północnych. Dz.U. z 1971 r. Nr 16, poz. 156. W związku z tym, że Kościół nie był użytkownikiem świątyni w Wolinie, nie przeszła ona automatycznie na je- 
Władze kurii w Gorzowie Wielkopolskim przygotowywały odpowiednią dokumentację dla wnioskowanych obiektów ${ }^{59}$. Na spotkaniach administracja kościelna oraz państwowe władze wyznaniowe ustalały wspólne stanowisko co do wnioskowanych obiektów. Dyskusja oraz osiagnięcie porozumienia w zakresie składanych przez Kościół postulatów były trudne ${ }^{60}$. Wydziały do spraw wyznań „podejmowały decyzje arbitralnie, dążąc do zachowania stanu posiadania przez instytucje państwowe; nastawione były na przekazanie jak najmniej obiektów kościelnym osobom prawnym" ${ }^{\prime 1}$. Kuria w Gorzowie przygotowała wykaz 136 nieruchomości z obiektami sakralnymi niebędącymi w użytkowaniu Kościoła katolickiego ${ }^{62}$.

Jak wcześniej wspomniano, kościół św. Mikołaja znalazł się również na liście skierowanej do władz wyznaniowych. „Wolin jest miejscowością o wielkich tradycjach historycznych, gdy idzie o życie religijne. Był siedzibą biskupstwa Kościół-katedra, z którego pozostały tylko wieża i ściany był zawsze własnością kościoła - przed reformacja rzymsko-katolickiego [...] Ruina stanowi zabytek - oburzenie wywołuje decyzja rozbiórki - a zdziwienie jej dotychczasowy stan zaniedbania. Ruina leży na bardzo uczęszczanym szlaku turystycznym. Wszystko przemawia za tym, by ją oddać z powrotem na własność kościoła Rzym.-Kat.”⒊ Realizowany w tym czasie projekt zabezpieczania obiektu jako trwałej ruiny „w naszym klimacie nie jest [nie

go własność. Rada Ministrów otrzymała uprawnienie - do końca 1973 r. mogła przekazać kościelnym osobom prawnym odpowiednim aktem (w tym wypadku uchwała) nieużytkowane kościoły. Zob. Mazurkiewicz, Spór o prawo własności kościelnych majatkón poniemieckich na Ziemiach Zachodnich i Pótnocnych w latach 1945-1973, „Studia Paradyskie” 2006, t. XVI, s. 237.

59 Por. ADZG, sygn. 1678, Różne pisma dotyczące spraw przekazania nieruchomości 1971-1972: Ks. Bp Ignacy Jeż, bp Wikariusz, Generalny, Gorzón Wlkp., dnia 21 marca 1972, Znak: B 2 - 11/72, Komunikat w sprawach wtasności kościelnej.

${ }^{60}$ K. Kozłowski, Narodziny diecezji sžczecinsko-kamieńskiej i koszalinsko-kotobrzeskiej (1945-1975), „Źródła do Dziejów Pomorza Zachodniego” (ZdDPZ) t. XIV, Szczecin 2007, s. 170-177: 1973 listopad 19, Warszawa. Protokót z rozmony przeprowadzonej w Urzedzie do Spraw Wyznań w Warszawie, w sprawie niek.tórych posycji z art. 2 diecezji szcrecińsko-kamieńskiej.

${ }^{61}$ Ibidem, s. 184: 1973 grudzien 28, Warsqawa. Fragment sprawozdania ze spotkania biskupón ziem zachodnich i pótnocnych z. wicepremierem Józefem Tejchma.

62 Por. AKDSK, teczka Art. 1, Art. 2 + sprawy dodatkowe, Art. 2. II kwestionariusz, Art. 2. III kwestionariusz: Wojewódzৃtwo szczecinskie, Diecerja gorzowska, wykaz nieruchomości z. obiektami sakralnymi niebędacymi w us̀ytkowaniu Kościoła katolickiego.

63 Ibidem, karta 136. 
był - autor] realny, a p. Kołodziejek [Kierownik Wydziału ds. Wyznań autor] powoływał się na opinię WKZ, że obiekt ten nie nadaje się już do odbudowy" ${ }^{64}$. Szczecińskie władze wyznaniowe zdecydowanie oponowały w kwestii przekazania zrujnowanego kościoła, jednak dyrektor Urzędu do Spraw Wyznań, Aleksander Merker przyrzekł, że urząd rozpatrzy sprawę ${ }^{65}$. Tak jednak się nie stało i kościół św. Mikołaja przez następne lata pozostawał trwała ruiną w gestii władz państwowych. Oczywiście biskupi nowo powołanej diecezji szczecińsko-kamieńskiej ${ }^{66}$ nie ustawali w staraniach o przekazanie obiektu. Podczas kolejnych spotkań kierownictwo Wydziału do Spraw Wyznań uzasadniało odmowę przekazania ruin tym, że na poczatku lat 70. oddano Kościołowi ponad 70 zrujnowanych świątyń, które należało odbudować, z czym wiązały się ogromne koszty i zapotrzebowanie na materiały. Na spotkaniu w 1980 r., dyrektor Wydziału do Spraw Wyznań oświadczył, że „wszystkie przepisy w sprawie przekazania ruin, skończyły się"67.

W 1981 r. Komisja Koordynacyjna NSZZ „Solidarność” w Wolinie wystosowała list do Ministra Kultury i Sztuki Józefa Tejchmy: „Solidarność w Wolinie uprzejmie prosi Pana Ministra o przyspieszenie decyzji dotyczącej oddania na własność Kościołowi Rzymsko-Katolickiemu, a konkretnie Diecezji Szczecińsko-Kamieńskiej i Parafii Wolin będącego w ruinie Kościoła w Wolinie przy ulicy Wojska Polskiego"68. Wniosek motywowano: „Istniejący stan ruin Katedry nie przynosi nam, mieszkańcom zaszczytu. Lecz przeciwnie wstyd, że tyle lat po wojnie nie potrafiono zlikwidować tego tak przytłaczającego widoku groźby wojny. Chcemy się szczycić nie ru-

\footnotetext{
${ }^{64}$ K. Kozłowski, ZdDPZ t. XIV, s. 175.

${ }_{65}$ AKDSK, teczka Rozmowy W/Wyznań 1973/1974: Protokót z rozmów w dniu 19.11.1973 w Urzedzie do Spraw Wyznań w Warszawie w sprawie niektórych pozycij art. 2 diecezji Szczecinsko-Kamieńskiej, s. 6.

${ }^{66}$ K. Kozłowski, ZdDPZ t. XIV, s. 114-119: 1972 č̣erwiec 28, Rży. Bulla papieża Pawta VI Episcoporum Poloniae coetus. Z administracji apostolskiej gorzowskie wyodrębniono jeszcze diecezję koszalińsko-kołobrzeską oraz diecezję gorzowską.

${ }^{67}$ AKDSK, teczka Szczecin: Protokót z rozmón jakie odbyt Ks. Roman Kostynowicz z Panem Dyrektorem Wydzialu do Spraw Wyznań, Henrykiem Kotodziejkiem, w dniu 5 XII 1980 r., s. 2.

68 AWUOZS, sygn. 1202, Zabytki nieruchome Wolin - Kościół św. Mikołaja: Pismo ZNNZ-B-W/81, Wolin, dnia 9.XI.1981 r., Obywatel Józef Tejchma Minister Kultury i Sztuki, Warszawa.
} 
inami, ale piękną budowlą, świadczącą o polskości Wolina. Odbudowany przez mieszkańców Wolina i okolic Kościół nada panoramie Wolina piękny i stosowny do jego historycznej przeszłości charakter. Każdy miesiąc trwania Katedry w ruinie powiększa jego zniszczenia i wzrasta koszt odbudowy, dlatego pragnęlibyśmy jak najwcześniej rozpocząć jego dobudowę ${ }^{69}$. Do Wojewódzkiego Konserwatora wpłynęło pismo z Ministerstwa Kultury i Sztuki, w którym poproszono o informację na temat sytuacji prawnoadministracyjnej oraz opinię konserwatorską dotycząca obiektu ${ }^{70}$. W odpowiedzi napisano między innymi: „W latach ostatnich nie było wystapienia ze strony władz kościelnych o przekazanie ruin. Wystapienie miało miejsce w roku 1971 i Urząd Wojewódzki odmówił przekazania z następującym uzasadnieniem: odbudowa budziła wattpliwości ze względu na stan techniczny (resztki ścian i wieży, nierównomierne osiadanie posadowienia), istniejacy kościół był wystarczający dla ludności m. Wolina"71.

W 1982 r. ks. biskup Majdański wnioskował do władz państwowych o przekazanie istniejących $\mathrm{w}$ diecezji nieczynnych kościołów ${ }^{72}$. W 1983 r. w piśmie do dyrektora Urzędu do Spraw Wyznań zamieścił wykaz 54 obiektów sakralnych będących w ruinie z prośbą o ich przekazanie diecezji. Znając historię i znaczenie świątyni zwrócił uwagę, że „na pierwszym miejscu należałoby postawić ruinę kościoła św. Mikołaja w Wolinie, a wszystkie inne traktować jako potrzebne duszpasterstwo"’3. Mając nadzieję, że świątynia przejdzie na własność Kościoła, przygotowywano niezbędną dokumentację do przyszłej odbudowy. Przeprowadzono inwentaryzację obiektu, która posłużyła do sporządzenia wstępnych założeń

\footnotetext{
69 Ibidem.

${ }^{70}$ Ibidem: Ministerstwo Kultury i Sztuki, Warszawa, dnia 19 listopada 1981 r., Ob. Mgr arch.

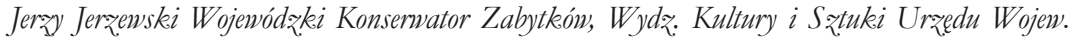

${ }^{71}$ Ibidem: Urzad Wojewódzki, Szrzecin, dn. 26 kwietnia 1982, Ministerstwo Kultury i Sztuki Zarzad Muzeón i Ocbrony Zabytkón Warszawa.

${ }^{72}$ AKDSK, teczka Materiały do sprawozdania (notatka odręczna). 27 IX 1982 r. do kurii wpłynęło w tej sprawie pismo od dyrektora UdSW.

73 AKDSK, teczka Szczecin: Biskup Szczecińsko-Kamieński, Szczecin, dnia 3 wržésnia 1983 r., Urzad do Spraw Wyznań w Warszawie, na rece Pana Dyrektora Mgr Aleksandra Merkera. W piśmie wymieniono również sprawę ruin kościoła w Chojnie, który należy do wyjątkowej klasy zabytków - „bardziej z racji kulturowo-historycznych niż duszpasterskich chcielibyśmy również ratować przez odbudowę". Ibidem.
} 
odbudowy ${ }^{74}$. Niestety kolejne wnioski o przekazanie kościoła rozpatrywane były negatywnie. W drugiej połowie lat 80 . w celu zapewnienia jednolitego trybu załatwiania spraw o przekazanie zrujnowanych kościołów władze wyznaniowe przygotowały i rozesłały prezydentom miast oraz naczelnikom miast i gmin specjalną instrukcję. Cała procedura miała być prowadzona na szczeblu wojewódzkim ${ }^{75}$, a objęto nią tylko obiekty, których przekazanie zostało wcześniej uzgodnione z Wydziałem do Spraw Wyznań. Nowe zasady i konsekwencja w działaniach władz kościelnych doprowadziły do pewnych rezultatów w sprawie przekazania ruin kościoła św. Mikołaja. „W 1986 roku do tut. Urzędu wpłynął wniosek proboszcza parafii w Wolinie w sprawie oddania w użytkowanie wieczyste działki Nr 55/1 położonej w Wolinie - obręb 3, na której znajdują się ruiny Kościoła św. Mikołaja. W związku z powyższym uprzejmie proszę o wydanie opinii dot. przewidywanych kosztów odbudowy obiektu co jest zgodne z $\int 15$ rozporządzenia Rady Ministrów z dnia 16 września 1985 r. (Dz.U. Nr 47, poz. 239)”76. W tym samym roku Wojewódzki Konserwator Zabytków w Szczecinie zakomunikował władzom miejskim w Wolinie, iż „ruina kościoła p.w. św. Mikołaja jest obiektem zabytkowym wpisanym do rejestru zabytków woj. Szczecińskiego pod poz. 374/59 i wyraża zgodę na jego dobudowę z przeznaczeniem na cele sakralne" 77 .

74 Zob. AKDSK, T. Ziółkowski, Obiekt - ruina obiektu sakralnego. Miejscowość - Wolin. Województwo - szrzecinskie, lipiec 1983; AKDSK, Wstępne zatożenia odbudowy obiektów sakralnych bedacych w ruinie nieprzekazanych dotychczas diecezji. Diecerja: szczecinsko-kamienska, Szczecin 1983.

75 „Przedstawicielom Kurii Biskupiej wyjaśniliśmy, że ewentualne przekazywanie wspomnianych obiektów [ruin kościołów - autor] do odbudowy będzie koordynowane na szczeblu właściwych wojewódzkich organów administracji państwowej [...]. Poinformowaliśmy ich również o obowiązujących przepisach dotyczących przekazywania nieruchomości państwowych w trybie postępowania przy załatwianiu tych spraw. Kuria zobowiązała się przekazać stosowne zalecenia zainteresowanym parafiom, a w szczególności spowodować, aby tylko proboszczowie występowali w tych sprawach z formalnymi wnioskami do właściwych terenowo organów administracji państwowej". AKDSK, teczka Ruiny 1985: Urzqd Wojewódzki Wydziat do Spraw Wyznań w Szczecinie, Szczecin, 1986 III 07., WZ. 8224/5/86, Presydenci Miast, Naczelnicy Miast i Gmin, Naczelnicy Gmin, -wssyscy-.

${ }^{76}$ Ibidem, Naczelnik. Miasta i Gminy Wolin, Wolin, 1986.03.20, Wojewódðki Konserwator Zabytkón, Ob. Mgr Krystyna Loose w Szrzecinie.

77 AWUOZS, sygn. 1202, Zbytki nieruchome Wolin - Kościół św. Mikołaja: Urzaqd Wojewódžki Wydział Kultury i Sztuki Wojewódzki Konserwator Zabytkón, Szczecin, 1986-05-10, Obywatel naczelnik Miasta $i$ Gminy w Wolinie. 
Postępowanie związane z przekazaniem ruin kościoła zostało przeprowadzone w 1988 r. $^{78}$

\section{Summary}

\section{St. Nicholas Church in Wolin. History of the building in the years 1945-1988.}

WWII brought great devastations to Poland. The so-called Recovered Lands were particularly destroyed. Monuments taken over after the war on Western and Northern Lands were destroyed the most in the Szczecińskie province. A detailed estimation of losses was impossible due to the situation after the liberation. Among ruined buildings there were about 200 sacral buildings. One of the examples is St. Nicholas Church in Wolin. The post-war history of the church shows a complicated situation of sacral buildings in a new post-war reality. Initially, the church administration took over churches that were not destroyed or were devastated to a small extent. In the following years state religious authorities stopped transferring unused ruined churches. By the mid-50s no securing works were performed, authorities did not foresee a reconstruction of the St. Nicholas Church.

For several dozens of years restoring authorities did not have a concept what to do with St. Nicholas Church. The absence of any decision resulted in a bigger and bigger devastation of the building. Under the pretence of a liquidation of war destructions, legally, a slow but regular demolition of the building started. In the end of the 1960s works were started in order to secure the building as a permanent ruin. The church administration many times tried to take over the building. However the situation did not change even after a treaty between Poland and the Federal Republic of Germany was signed. State faith authorities tried to maintain their possessions at all costs - even if sacral buildings were the case. Big 'social movements' in the early 1980s changed this situation. A slow and difficult process of taking over the building was started. The church was regained in the late 1980s. The church and society could start the reconstruction of the church.

78 Ibidem, Raymsko-Katolicka Parafia w Wolinie, Wojewódẓki Konserwator Zabytków w Szrzecinie, Wolin 1988.06.10. 


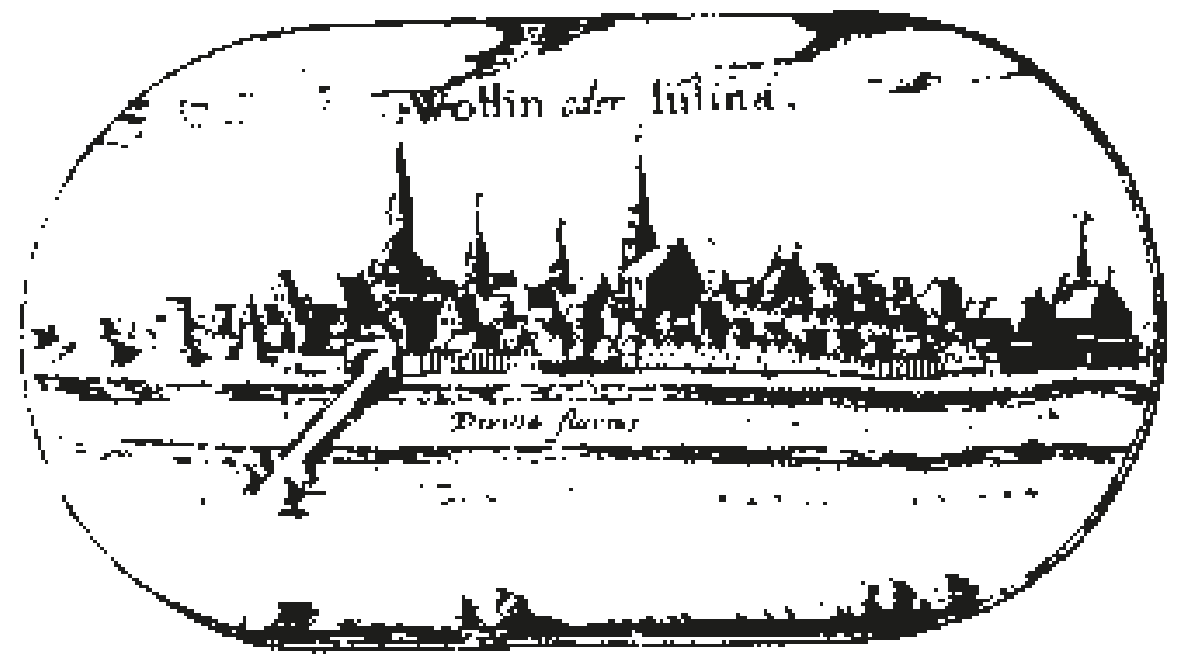

Il. 1. Panorama miasta Wolina z Wielkiej Mapy Księstwa Pomorskiego wg Lubinusa, (1618 r.), za: http://pl.wikipedia.org/wiki/Wolin_(miasto)\#/media/File:Lubinus_Wollin.png 


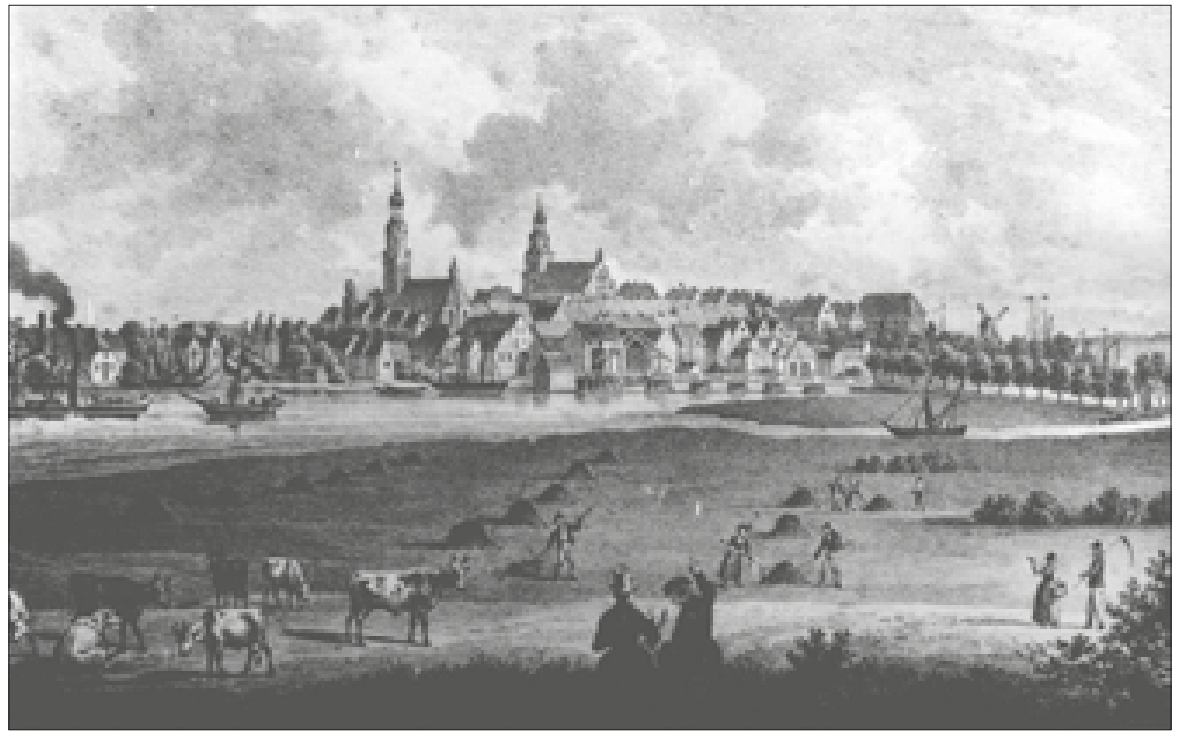

Il. 2. Wolin w XIX w., w centralnym miejscu kościół św. Mikołaja, za: bttp://pl.wikipedia. org/wiki/Historia_miasta_Wolin\#/media/File:Wolin_XIX_wiek.jpg

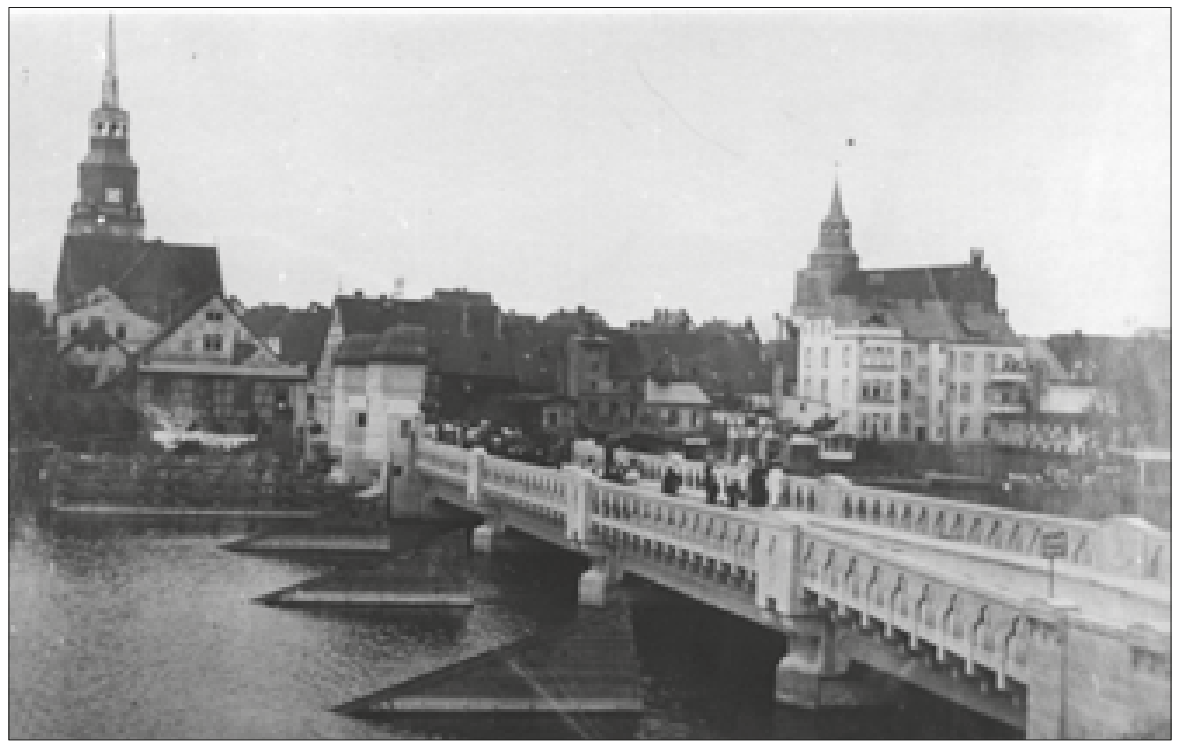

Il. 3. Wolin, początek XX w., po prawej stronie kościół św. Mikołaja, za: http:// upload.wikimedia.org/wikipedia/commons/1/19/Wolin_XX_wiek.jpeg 


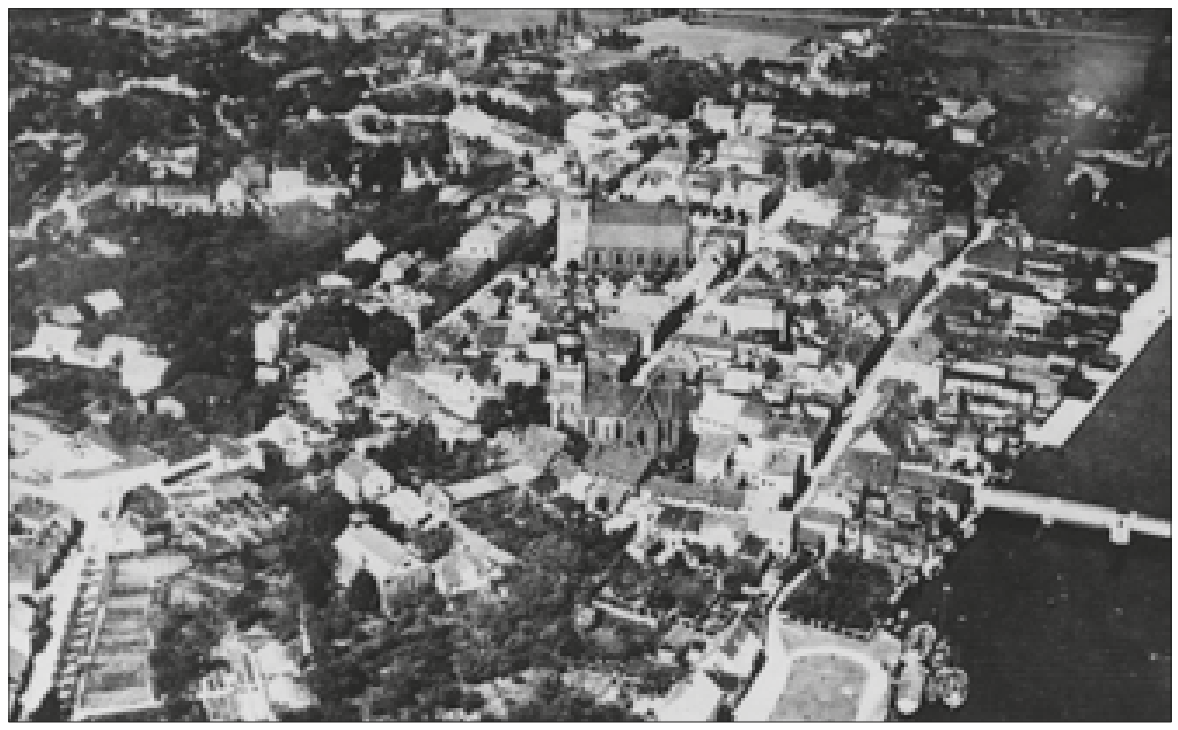

Il. 4. Wolin, XX w., na drugim planie sylweta kościoła św. Mikołaja, za: bttp://pl.wikipedia. org/wiki/Wolin_(miasto)\#/media/File:Wolin_Panorama.jpg

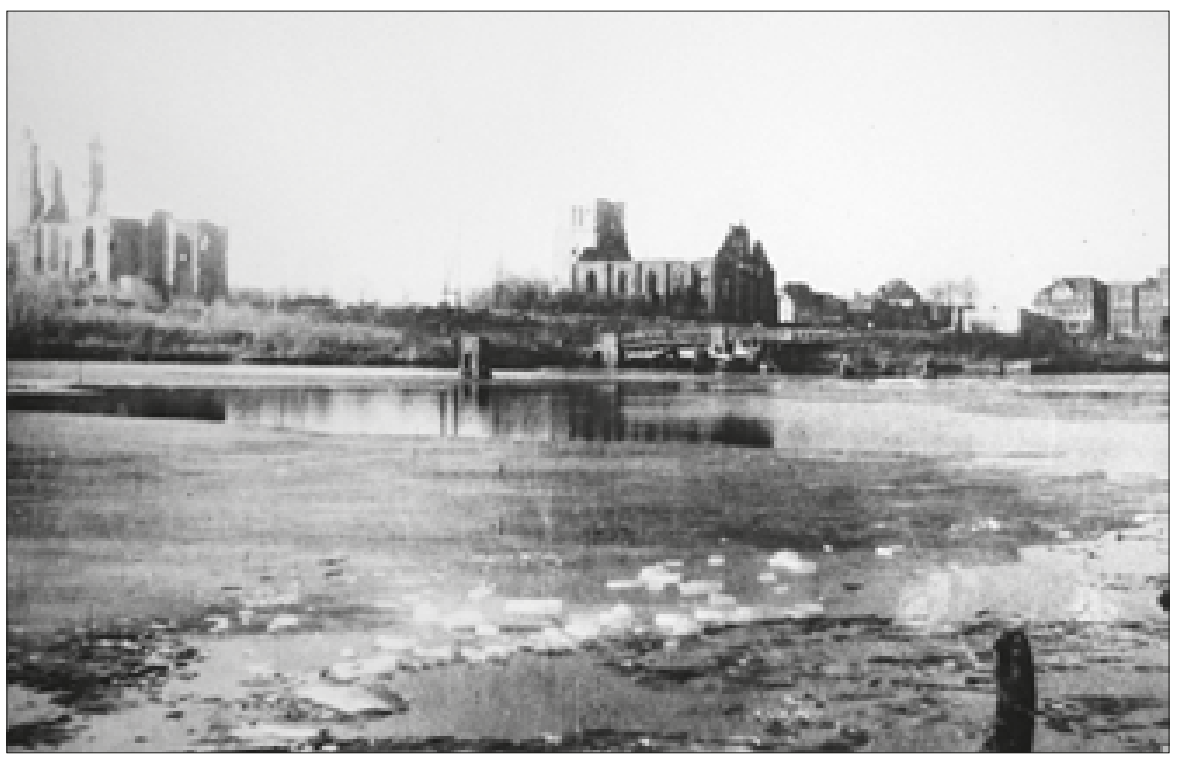

Il. 5. Wolin, ok. 1957 r., w centralnym miejscu ruina kościoła św. Mikołaja, za: Studium historyczno-urbanistyczne miasta Wolina, Poznań 1958, il. 16 


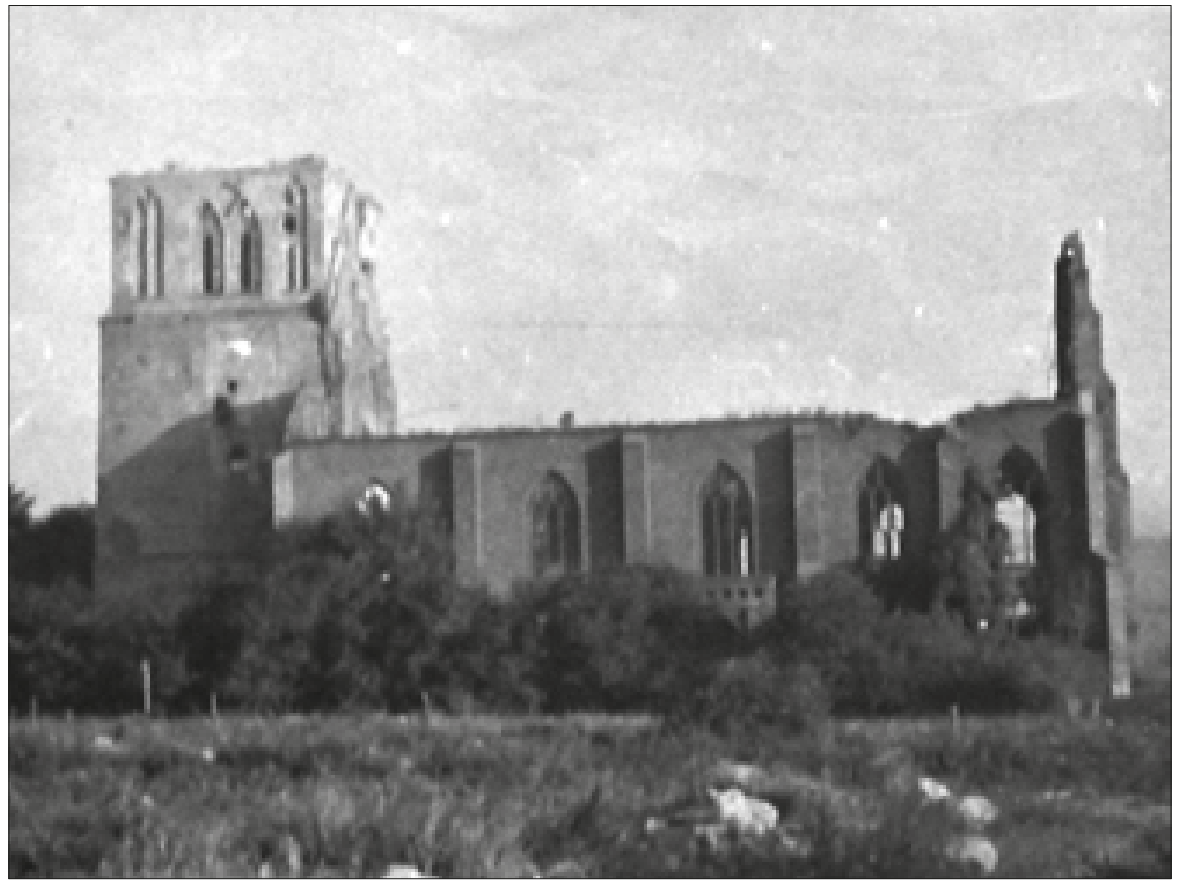

Il. 6. Ruina kościoła św. Mikołaja około 1959, za: AWUOZS, KOZ, Wolin, 1959, brak autora 


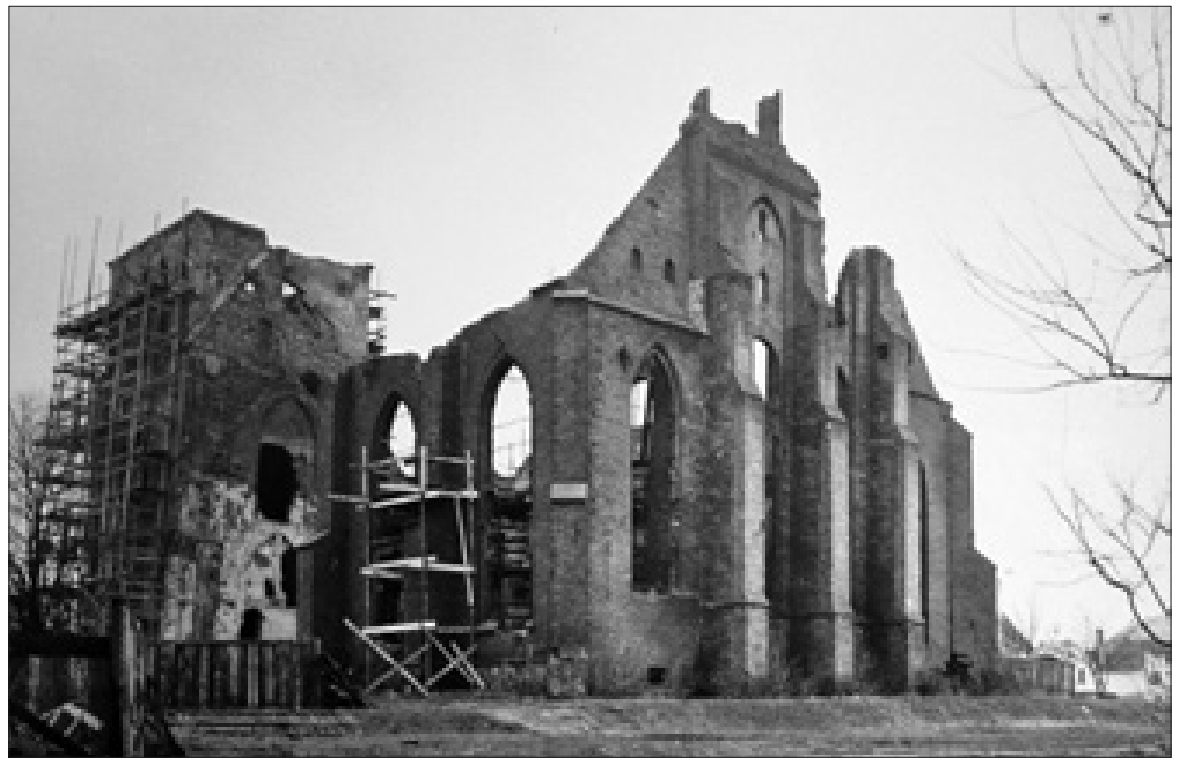

Il. 7. Kościół św. Mikołaja, około 1973, za: fot. G. Solecki, [w:] K. Kalita, Kościót św. Mikołaja w Wolinie. Dokumentacja historyczno-architektoniczna, PKZ Szczecin 1973 


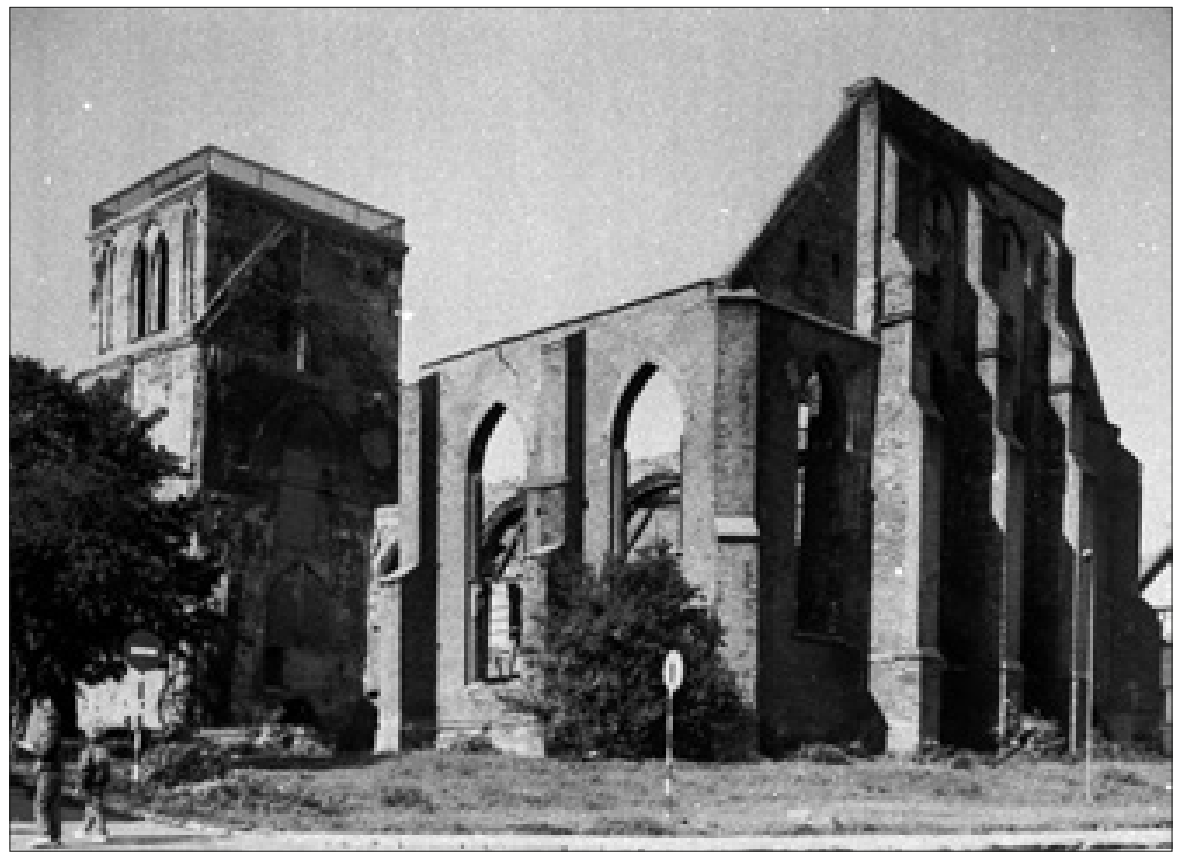

Il. 8. Wolin, kościół św. Mikołaja, lata 80, za: AKDSK, KOZ, Kościót św. Mikołaja. Wolin 